\title{
Göçün Türkiyeli Kadınlar Üzerine Etkileri: Almanya Örneği*
}

\author{
Eda Özyurt Kılınç
}

\begin{abstract}
$\ddot{O} z$
Toplumsal cinsiyet konusu dünya çapında önem taşıyan bir konudur. Toplumsal farklılıklara yansıması ve kıyaslamalar, konuyu üzerinde çalışmak için ilgi çekici kılar. Bu çalışmada üzerinde çalışılan göç konusu gibi bazı faktörler, cinsiyet ayrımcılı̆̆ını pekiştirir bir niteliğge sahiptir. Bu araştırma, cinsiyet ayrımcılı̆̆ perspektifinden bakarak, göç olgusunun Almanya'da yaşayan Türkiyeli kadınların üzerindeki etkilerini inceleyen bir çalışmadır. 1960'l yıllardan itibaren, Avrupa ülkelerinin ucuz işgücü talebiyle birlikte insanlar, Türkiye’nin özellikle kırsal bölgelerinden Avrupa'ya göç etmişlerdir. Türkiye toplumu kültür erozyonuna sebebiyet vermemek için ataerkil aile yapısını, farklılıklarını, annleri, eşleri ve kız çocuklarını namus başlı̆̆l altında kullanarak, Almanya ve Türkiye arasında adeta demir perde gibi sunmuştur. Türkiye kültüründe var olan cinsiyet eşitsizliği göç faktörüyle birleştiğinde, kadınların içinde bulunduğu durum, içinden çıkılmaz bir hal almaktadır. Kadınlar iki kültür arasında sıkışıp kalmakta, bir yandan modern toplum diye tarif edilen topluma benzemek istemekte, bir yandan da geleneklerin ebedi koruyucusu olma göreviyle yetiştirilmektedir. Türkiye'de ise bu durum kadınlarca bu denli bir tehdit unsuru olarak algllanmamaktadır. Bu sebeple Türkiye'deki kadınlar değişime görece daha açıktır.
\end{abstract}

Anahtar Sözcükler: Emek göçü, Göçmen kadınlar, Toplumsal cinsiyet, Aile içi şiddet, Ataerki.

\section{Effects of Migration on Turkish Women: Germany Example}

\begin{abstract}
Gender issue is a major problem around the world and the reflections on societal differences and comparisons make the subject attractive to study. Some factors such as migration which I study on strengthen the impact of gender discrimination. In this regard, this study examines Turkish society in Germany in the aspect of gender mainstreaming. Since 1960's, with the demand of cheap labor force of European countries, people have migrated from mostly rural part of Turkey to Europe. Turkish society, against the threats of spoiling their culture, introduced their patriarchal background like an iron curtain between German and Turkish society which indicates the concrete differences using mothers, wives and daughters as the honor of Turkish family. Inequality which already exists in Turkish culture becomes worse when migration is in question as the women are in dilemma between Turkish and German culture. On one hand, they would like to resemble the modern society but on the other hand, they are regarded as the eternal defender of the patriarchal traditions. Whereas in Turkey, there is not as much threat as in Germany for women to preserve the borders of Turkish identity so women in Turkey are relatively more open to the evolution.
\end{abstract}

Keywords: Labor migration, Migrant women, Gender, Domestic Violence, Patriarchy.

* Bu çalışma 2005 yılında, Berlin'de erkek kardeşleri tarafından aile kararıyla öldürülen Hatun Sürücü’ye ithaf edilmiştir.

1 Uçan Süpürge Kadın İletişim ve Araştırma Derneği Sosyal Çalışmacı Adres: Ergazi Mah. Şehit Soner Çankaya Sok. Star Sitesi B Blok No:5 Batıkent/Ankara E-mail: edaozyurtkilinc@gmail.com 


\section{Giriş}

Yarım yüzyıl süren göçün Almanya'da kalıcı olmasında Türkiyeli göçmen kadınların rolü büyüktür. Almanya ile müttefiki olan Türkiye arasında imzalanan Türk-Alman İşüucü Anlaşması, savaş sonrası bitap düşen Almanya'yı güçlendirmek amacıyla imzalanmıştı. Türkiye'nin muhtelif yerlerinden tam da Türkiye' deki köyler ve kasabalardan büyükşehirlere çalışmak, para kazanmak için göçün arttığı zamana tekabül eden yıllarda Almanya’ya da göç başlamıştı. İstanbul, Adana, Ankara gibi göç merkezlerinin yanında Almanya da vardı ve Almanya firsatı herkesin eline geçmiyordu. Almanya’yı Türkiye'deki büyükşehirlere göçten farklı kılan ise göçün emek göçü olmasıydı. Win-win ilkesini baz alan iki ülkenin çıkarları şöyleydi; Almanya cüzi meblağlarla ve ağır işlerde fabrikalarda çalışacak göçmenlerle kalkınacak, Türkiye vatandaşları ise "heim-işçilerin hep birlikte kaldığ 1 yurtlar"da kalarak para biriktirecek, ailesine gönderecekti ve Türkiye'ye de böylelikle döviz girecek ve emek göçü Türkiye'nin de kalkınmasına hizmet edecekti. Hem Almanya hem de Türkiye için tasarlananlar doğruydu ancak göçün sosyolojik boyutu gözardı edildiği için olası çarpan etkileri tasavvur edilemedi.

Misafir işçi terimi, göçmen işçileri Almanların gözünde misafir k1lıyordu, bu birgün döneceklerini işaret ediyordu ama ne zamana kadar çalışacakları ve ne zaman dönecekleri muğlaktı. Almanya Hükümeti, ileride başına dert edeceği şeyleri o yıllar henüz düşünememişti çünkü o yıllarda esas amaç Almanya'yı ekonomik buhrandan kurtarmaktı. Yunan, İtalyan, Yugoslav, İspanyol ve Türk göçmenler harıl harıl çalışıyor, geri kalan zamanlarında da nefes alabilmek için belki de fabrika haricinde tek görünür oldukları eğlence mekanlarında işçi arkadaşlarıyla birlikte zaman geçiriyorlardı. Türkiyeli göçmenler köylerinden sonra ilk defa adım attıkları yeni bir dünyanın keşfindeydi aynı zamanda. Erkek işçilerin cinsel anlamda da dahil oldukları yeni bir dünya, geride bırakılan Türkiye'de eşlerini bekleyen kadınlar için pek de adil durmuyordu. Fakat özgür cinselliği sadakatsizlik değil, erkeğin hakkı olarak görmek zorunda kalan kadınlar, ihtiyaç olduğunu düşünerek paradokslar barındıran toplumsal ahlak mekanizmasını işletip, bu eylemi meşrulaştırma yoluna gitmişti. İnsan ruhundaki acıların bâki kalması ise toplumsal ahlak normlarının konusu değildi.

Almanya'ya ilk giden misafir işçi kafilesinin çalıştıkları süre boyunca kalacakları yerler "heim”lar olacaktı. Banyo ve tuvaleti ortak kullanan işçilerin özel alanları odalarıydı ve işçilerin çok azı kadındı. İşçilerin Almanya'da kalma süreleri uzadıkça, göçmenlerin Almanya’ya yerleşme oranları da arttı. Yerleşme oranlarının artmasıyla birlikte, aile birleşimleriyle Almanya'ya artık işçilerden çok işçilerin Türkiye'de bıraktıkları eşleri ve çocukları gelmeye başladı. Bir ailenin "heim"larda kalması ise pek olası değildi, bu durum yeni bir eve çıkma gereksinimini beraberinde getirdi. Bu da Almanya'ya yerleşmenin temelini oluşturdu ve Türkiyeli göçmenlerin birçoğu artık dönmedi, dönemedi. Misafir işçi (gastarbeitar) terimi kullanımdan kalkmış, göçmen işçiler terimi kullanılır olmuştu. Almanya halkı içinde hakim olan görüşü ise İsviçreli yazar Max Frish dillendirecekti; "İş gücü istendi ama insanlar geldi”2. Misafir işçiler, dünyadaki diğer tüm göçmenler gibi Almanya’ya resmen musallat olmuştu (Saybaş1lı, 2011). Saybaşılı'nın tabiriyle; yahudilerden sonra, ülkeye musallat olan yeni hayaletler Türkiyeli misafir işçiler olacaktı. Belki de misafir işçiler, tekinsiz kıldıkları mekânlarında hayaletken artık görünür olabilmeyi yerleşik hayata birlikte geçtikleri eşleriyle sağlayacaklardı.

2 Zafer Özcan, Aksiyon Dergisi(2008) http://www.aksiyon.com.tr/aksiyon/haber-23773-34-biz-iscileri-cagirdik-ama-insanlar-geldi.html (4 Haziran 2010 tarihinde ziyaret edildi) 
Türkiye diasporasının görünür olduğu zamanın, Almanya'da eşlerine, kız çocuklarına yönelik şiddet, namus cinayeti gibi vakalarla tanındıkları zamana denk gelmesi bir tesadüf müdür? Almanya'ya musallat olan hayalet işçilerin aile birleşimi ile yerleşik hayata geçmeleri, göçmen işçiliğe geçişin de başlangıcı olacaktı. Türkiye'den kadın ve çocuklar, adeta yangın anında ilk kurtarılması gereken kişiler gibi Türkiye'den kurtarılacak ve “düşler ülkesi” Almanya'ya gönderileceklerdi. Fakat aile birleşimi yasası ile Almanya'ya gelen kadınları, Türkiye'de kadın olmalarından kaynaklanan ayrımcılıktan ötesi bekliyordu. Kadınlar ve çocuklara kurtuluş Almanya'da gelmeyecekti. Türkiye kırsalında maruz kalınan şiddetin tüm türlerinin Almanya'da da kadınları bekliyor olmasının yanında, kadınların Almanya'da olmalarından kaynaklanan “dış etkenler” sebebiyle de davranışları kısıtlanacak, kadınlar Türkiye'de komşuları ile kurdukları ilişkileri Almanya'da kuramayacak, şiddet gördüklerinde yardım elini isteyecekleri ailelerini Almanya'da bulamayacak, bu da göçmen kadınlarda yalnızlık duygusunu iki katına çıkaracaktı. Dış mekanların yani sokakların erkeklere ait olduğu, dolayısıyla erkek dayanışmasının yalnızlık duygusunu alt edebilmeyi daha mümkün kıldığı gerçeği, erkeklere, sorunlarını aşmalarında yardımcı olacaktı. Kadınlar ise tüm duygusal tepkimelerine ket vuracak ve Anadolu'da yıllardır süregelen "kol kırılır yen içinde kalır" sözünü kendilerine felsefe edineceklerdi. Göç, kadına yönelik şiddetin boyutunu arttıran önemli bir faktördü. Türkiye'de kadınlar ve kız çocuklar ailenin namusu olurken, Almanya'da tüm Türkiye diasporasının namusu olacaklardı. Almanya'daki namus Türkiye'dekinden bu nedenle daha da ağır gelecekti. Türkiyeli kadınların Almanya ve Türkiye halkları arasında demir perde gibi sunulmasının, Almanya'nın 1989 yılına kadar doğusunu ve batısını ayıran demir perdeden pek farkı yoktu. Fark eden şey, zamanın gerektirdikleriyle demir perdenin yıkılabilmesi; fakat kadınların namus ve kültürel dokuyu Almanya'da muhafaza etme sorumluluğunun duvardan daha kalın ve yıkılmaz olmasıydı.

\section{Yöntem}

Bu makale 2010 yılında, Berlin ve Leipzig şehirlerinde Akarsu Derneği, Dersim Cemaati, Alevi Birlikleri Konfederasyonu, BIG: Berliner Gegen Gewalt kuruluşlarından gönüllüler ve diğer gönüllü olan 12 kadın ile gerçekleştirilen görüşmeler ile Almanya'ya emek göçü ve toplumsal cinsiyet temaları üzerine yazılmış tezler ve ilgili kitaplar, filmler, göçmen sinemasından edinilen bakış ve Özyurt (2010)'un köşe yazıları baz alınarak hazırladığı tezinden alıntılanarak hazırlanmıştır. Bu çalışmada gözlem, kapsamlı gözlem ve yoğun gözlem teknikleri ile veriler toplanmıştır. Görüşülen kadınlar, güvenliklerinin sağlanabilmesi için sırasıyla alfabenin harfleri ile kodlanmışlardır. Örneklem grubu olarak seçilen kadınlarla yapılan görüşmelerin ardından tümevarım yöntemi ile bir sonuca ulaşılmıştır. Bu makale; emek göçü, toplumsal cinsiyet ve bu bağlamda incelenen aile birleşimi konusunu irdelemektedir. 


\section{Bulgular}

\section{Aile Birleşimi ile Almanya'ya Göç}

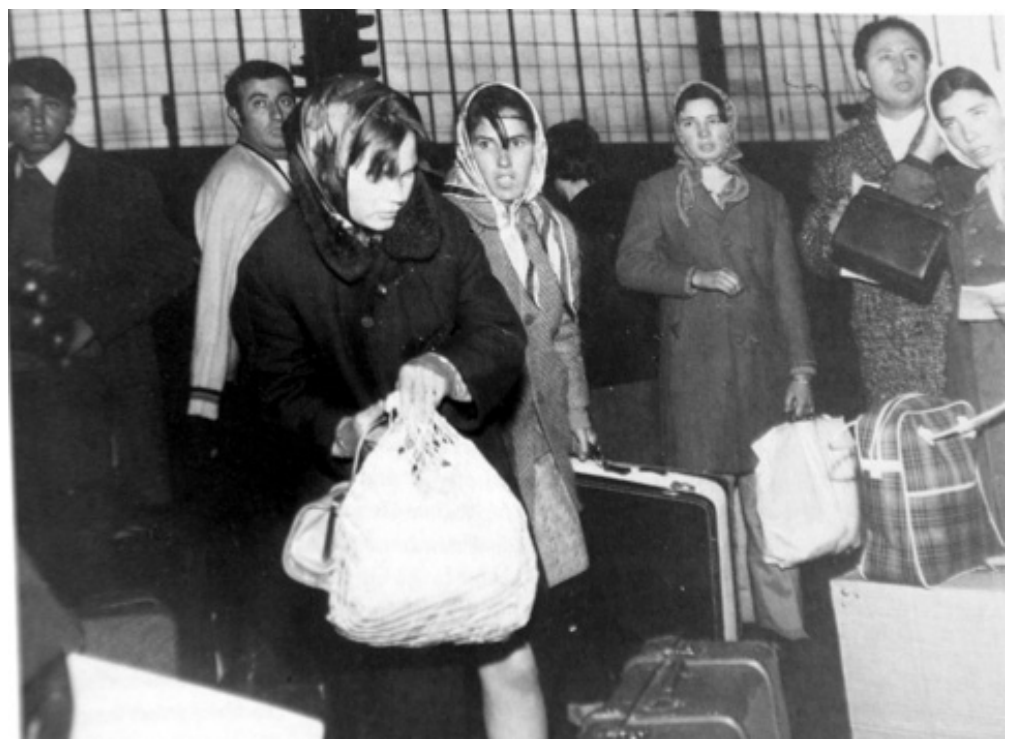

Almanya'ya göç eden ilk kafile, ailelerini ardlarında bırakmış, bir müddet çalıştıktan sonra Türkiye'ye dönmek yerine ailesini yanına almıştı. Ya da zaten bekâr olan göçmen işçiler pek tabii sebeplerle Almanya'daki kadınlarla evlenmek yerine kendisini memleketinde hissedeceği, Türkiye özlemini Türkiye'nin gelenek ve göreneklerine kendisini adamış kadınlarla evlenecekti. Avrupa'nın ezilmişleri olan göçmen işçiler, Anadolu'nun eli tarhana kokan, çoğunlukla akrabası olan kadınlarla bir yaz tatilinde evleniyor ve ardından aile birleşimi prosedürleri ile eşlerini yanlarına getiriyorlardı. Anadolulu kadınlar çok iyi yemek yapıyor, ev temizliyor, çocuk bakıyordu fakat tüm bu beceriler kadınları yine iç mekâna hapseden işlerdi. Anadolu'da en azından tarlada, çeşme başında sosyalleşen kadınlar için Almanya; tek göz oda anlamına bile gelebiliyordu. ${ }^{3}$ Anadolu'da sadece anneanne ve dedelere emanet edilen çocukları kreşe/kindergartena bırakmak Türkiyeli göçmenler için alışılmış bir davranış olmanın çok ötesindeydi. Çocuklara bakmak ve çalışma yaşamından azade bir hayat sürmek Almanya'da da yine kadınların kaderi oldu. Çalışmak ancak çocukları büyüdüğünde mümkündü. Belirli bir yaştan sonra Türkiyeli kadınların yıllar sonra yapacakları yegane ve en mükemmel iş ise hasta bakıcılığı ve hemşirelik olacaktı. ${ }^{4}$ Yıllar boyu kocaları, çocukları ve eşinin ailesine bakmalarından edindikleri tecrübe, Almanya'nın yaşlı nüfusunun sağlığı için çok önemli bir detaydı.

Almanya’ya göçün, göçmen kadınların yanında kız çocuklara da olumsuz etkileri oldu. 2010 yılında Berlin'de araştırmacı tarafından yapılan nitel görüşmelerde, bir kadın aile birleşiminin kendi hayatına hâlâ devam eden etkisinden şöyle bahsetmiştir:

“Benim ailem, ben üç yaşındayken Tunceli'den Almanya'ya göç etti. Sekiz kardeştik. Almanya'ya hazırlıklar esnasında babaannem, annemden benim kendileri ile kalmamı rica etti. Babaannemin bu isteği, kız çocuk olmamdan ötürü benim onlara ev işlerinde yardım edeceğimdendi. Annem babam böyle söylüyor, ben bilmem. Ben kendi ailemin gerçek ailem olduğunu yllarca bilmedim. Ben anneannem ve dedemin

3 Film: 40 Metrekare Almanya, Tevfik Başer, 1986, Hamburg, Almanya

4 Almanya'da görüştüğüm kadınların birçoğu, Almanya'daki Türkiyeli kadınların çoğunlukla hasta bakıcılığı ve hemşirelik yaptıklarinı belirtti. 
annem ve babam olduğu gerçeğiyle büyüdüm. Ylllarca ailemi görmeyeceğim için üzülmemem için gerçeği söylemediklerini söylediler. Köye gelip, beni ziyaret ettiklerinde, 14 yaşındaydım. Şoktaydım, inanamadım. Beni Almanya'ya götürdüklerinde, erkek kardeşlerim bana üvey kardeş muamelesi yaptılar. Üç yıl aynı evde yaşadık ve birbirimize alışamadık, tam alıştık derken; evlendim. ",5

Aile birleşimleri, kadınların hayatına olumsuz bir etken olduğu gibi aile kurumunu da derinden sarstı. Erkekler Almanya'da daha önce deneyimlemedikleri bir yaşam tarzı ile karşılaşıp başka bir hayat perspektifi kazandılar ya da kültürel deformasyon olduğunu düşündükleri Alman kültüründen korunabilmek için daha da muhafazakarlaştılar. Erkeklerin iki farklı yöne evrilmesinin, kadınların hayatında farklılaşan bir karşılığı yoktu. Her iki durumda da kadın ataerkil şiddetin mağduru oldu.

Demirci, “Almancıların Çocukları” isimli kitabında, bir öğretmen olaraköğrencilerinin aileleri için yazdığı mektupları birleştiriyor. Mektupların birçoğu Aile Birleşimi Yasasıyla Almanya’ya gelen ailelerin durumunu gözler önüne seriyor. Çocukların birçoğu mektuplarında Almanya'ya geldikten sonra babalarının değişimlerinden dem vuruyor; babalarının alkol bağımlılı̆̆ı, annelerini aldatmaları ve Almanya'ya geldikten sonra babalarının hayatlarını kısıtlaması en çok şikayet ettikleri konular oluyor (Demirci, 1997: 61). Öğrencilerin anlatımları, çoğunlukla babalarının olumsuz yönde değiştiği yönünde oluyor. Nihai olarak anlaşılan, çocukların babalarının artık köylerindeki kadar "temiz" olmadığı, yani Almanya'nın babalarını bozduğu şeklinde oluyor. Öğrencilerden biri mektubunda babasının muhafazakarlaştı̆̆ konusundaki şikayetlerini şöyle dile getiriyor:

“Ramazan ayıydl, Türkiye'den bir imam geldi ve onu akşam yemeğine davet ettin. Imamın bir kaç tavsiyesinden sonra, beni Almanca kursuna göndermek yerine Kur'an kursuna göndermeyi tercih ettin. Annem biz kasabadayken başl açık gezerdi, şimdi ise annemin başını kapatmasını istiyorsun. Başını örtmesi için onu zorlamaya başladın!’ (Demirci 1997, s.61)

Buradan da anlaşılacağı gibi ataerkil baskı ve din, göçmenlerin değişmediği aksine geleneklerini koruduklarını gösterme işlevi görüyor. Fakat gelenekler erkekler için değil kadınlar için işliyor.

Almanya'ya geldiğine pişman olduğunu belirten Kadın C görüşünü şöyle dile getiriyor:

“Bence Türkiye'de yaşayan kadinlar bizden daha şanslılar. Biz burada geleneklerin koruyucusu olarak görülürken, Türkiye'deki kadınlar gelişmeye daha açık. Biz kendimizi geliştirmek istesek bile önümüzde bir sürü engel var." 6

\section{İthal Gelinler}

Almanya'daki aileler genellikle çocuklarını Türkiye'den biriyle evlendirme eğilimindedirler. $\mathrm{Bu}$ tür evlilikler genellikle muhafazakar aileler tarafından benimsenen evlilikler olmakta, zira Türkiye'de büyüyen gelin adaylarının Almanya'dakilere nazaran daha geleneklere bağlı ve daha saf olduklarını düşünmektedirler. Damat adayları ise ailenin mesleki ihtiyaçları doğrultusunda seçilmektedir. Yine de Türkiyeli ailelerin bu tür evliliklere bakışı günden güne değişmektedir. Çünkü Almanya'da bulunan Türkiyelilerin artık makro-topluluk düzeyinde oldukları, yeni jenerasyon ile birlikte Türkiye'den gelin arayışlarının artık azaldığı da biliniyor. Neden hâlâ bazı aileler Türkiye doğumlu gelin istiyorlar?

5 Kadın A: 45 yaşında. Aile birleşimi ile Tunceli'den 14 yaşında göç etmiş. İlkokulu Türkiye'de bitirmiş. Eğitimine Almanya'da devam edip, dokuzuncu sınıfa kadar okumuş. 24 Mayıs 2010 tarihinde Berlin'de görüşme yapıldı.

6 Kadın C: 43 yaşında, aile birleşimi ile Sivas'tan göç etmiş. Türkiye'de ilkokula kadar okumuş, Almanya'da dokuzuncu sınıfa kadar okula devam etmiş. Hemşire olarak çalışıyor. 16 Mayıs 2010 tarihinde Berlin'de görüşüldü. 
Türkiyeli kocalar, eşlerinin Almanya'daki normlara uyum sağlamasından korkuyor, çünkü özellikle Almanya'da doğan kadınların bağımsız bir hayat sürdürdüğüne ilişkin kanı, Almanya'da doğup büyüyen yeni jenerasyonu Türkiye'den "gelin almaya” yöneltiyor. Türkiye'den biriyle evlenmek, Türkiye ile ilişkilerin hâlâ devam ediyor olması ile namusun ve geleneklerin korunmasını da sağlıyor. Namus sadece bireysel değil aynı zamanda da toplumsal bir ifade. Ailenin namusunun yitirilmesi, aynı zamanda göç edilen ülkenin asimilasyon politikasına da yenik düşmek anlamını içeriyor. Böyle bir durumda namus kavramı; asimilasyona karş1 göçmenlerin kültürlerini koruyan, kültürlerini Almanyalılardan farklı kılan yegâne olgu olarak sunuluyor (Kaya/Kentel 2005, s.153).

Almanca bilmeyen ve bu nedenle ilk geldiğinde çalışamayan gelin, Türkiye'den Almanya'ya göç ettiğinde, kocasına ve kocasının ailesine bağımlı kılınıyor. Özgürce hareket edebilmek, ekonomik özgürlükle ilişkili olduğu için Türkiye'den göç eden yalnız gelin, kocasına bağımlı olmak zorunda kalıyor. Anadolu'da yaygın bir terim olan "yabancıya gitmemek" ise Almanya'daki göçmenleri kendi akrabalarından biriyle evlendirmeye zorluyor. Almanya' ya gelin gelen kadınlar; (geleneklere bağlılık, okula devamın yarıda kesildiği, ekonomik özgürlükten azade bir hayat gibi özellikleri barındıran böylesi bir durum çocuk evliliğini işret ediyor) ilkokuldan ya mezun ya da iki veya üçüncü sınıftan terk olan ve 16, 17 yaşlarında evlendirilen kız çocuklardır. Özellikle zorunlu bilinçsizlik sebebiyle kadınlar Almanya'da eve mahkum olurlar.

Kadın B, Kahramanmaraş olaylarında, ailesini kaybetmesiyle yapayalnız kalmış ve Almanya'daki kuzeniyle bir yaz tatilinde evlendirilmiştir. Söz konusu kadın kendi evlilik hikayesini şöyle anlatıyor:

"Amcam ailesiyle birlikte Almanya'ya göç etti ve yıllar sonra beni köyde ziyaret ettiler. Amcamın oğlu beni görmüş beğenmiş. Ardından evlendik ve ben Berlin'e geldim. Hamile kaldığımda 17 yaşındaydım ve hiçbir şeyden haberim yoktu, nasıl evlenilir ve nasıl hamile kalınır ya da korunur kimse söylemedi. Bu yüzden Almanya'ya geldiğim ilk sene hamile kaldım. Almanca öğrenmem için polis kapımı çaldığında, henüz doğum yapmuştım, bu yüzden okula gidemedim."

Türkiye'deki ailelerin ise sınır ötesi evlilik söz konusu olduğunda, yüksek beklentileri olmaktadır. Kızlarını Almanya'ya gelin vermek, hem ailenin itibarının artması hem bir ayaklarının Almanya'da olması ve kızları aracılığıyla ailenin refah düzeyinin artacağını garanti altına alarak hayırlı bir işe adım attıklarını düşünmeleri, ailelerin kızlarını Almanya'ya gelin göndermelerinde etkin bir sebep olmaktadır. Türkiye'deki aileler için, Amanya'ya giden insanların ellerinin altın tuttuğu düşüncesi hâlâ yaygın bir inanıştır. Aslında bu düşüncenin dayandığı bir gerçeklik de vardır, fakat 2008 yılında patlak veren ve günümüzde etkileri hâlâ devam eden Avrupa'daki ekonomik düşüş sebebiyle artık bu gibi beklentilerin karşılanabilir olmadığı bilinmektedir. Kız çocuklardan Almanya'da bir akraba ile evlenmeleri yolu ile ailenin ekonomisine katkıda bulunmaları beklentisi, kızları Almanya' da mutsuzlukla karşı karşıya bırakmaktadır. Almanya'da hayata hemen karışabilmek meslek sahibi olmayan ve dil bilmeyen kadınlar için uzak bir gelecektir. Bu gibi durumlarda kadınlar genellikle yalnız kalmakta ve erkeklerin baskıcı davranışları ile kadınları eşlerine daha da bağımlı hale getirmektedir. Örneğin erkekler, eşlerinin eğitim alması ya da dil öğrenmesinin önüne engeller koyabilmekte ve eşlerinin çalışmasına izin vermemektedir (izin vermemenin birçok yolu vardır ve bu yollardan bazıları da tercihi kadınlara bırakıyormuş gibi bir izlenimle aslında çalışmasına engel olmaktır). Sonuç olarak kadınlar, bugünlerde Avrupa Birliği’nce “dahil etme/inclusion” olarak

7 Kadın B: 47 yaşında, Kahramanmaraş’tan Berlin’e 15 yaşında evlilik sebebiyle göç etmiş. İlkokul mezunu. 16 Mayıs 2010 tarihinde Berlin'de görüşüldü. 
ismi değişen fakat Almanya'da yıllarca söylenegelen entegrasyon politikaları konusunda en çok mağdur olan kitle oldular ve kısır döngüden nasiplerini şöyle aldılar: dil öğrenemedi, meslek sahibi olamad1, çalışamad1, ekonomik özgürlüklerini alamadı ve şiddetin mağduru oldular. Almanya’ya gelin gelen kadınların ailelerini Türkiye'de bırakmaları, aslında Almanya'da yalnız oldukları ve muhattap olmak zorunda kaldıkları yegane kişilerin eşleri ve eşlerinin aileleri olması, kadınların problemlerini kimseye anlatamamaları anlamına gelmektedir. Göçmen kadınların Almanya'da karşılaştıkları problemler, genellikle eşi ve ailesinin geleneksel baskısı sebebiyle karşılaştıkları problemlerdir ve Türkiye'de her yeni evlenen kadının karşılaştı̆ğ sorunlarla neredeyse aynıdır fakat sorunlarını eşine ve ailesine yansıtması özellikle kendilerini Türkiye'dekinden de çok "elin evinde" ve yalnız hissetmesi sebebiyle kadınların imtina ettiği bir davranıştır. Ve sorun olduğunu anlayan ailelerin ise gelin getirdikleri kadına; "Bizim sayemizde Almanya'ya geldin, daha ne istiyorsun?" minvalinde hoşgörüden eksik ve Almanya’yı bulunmaz bir nimet gibi gösteren çıkışları, göçmen kadınların içinde bulundukları durumu daha da içinden çıkılmaz bir hale getirmektedir. Aile birleşimi aracılığıyla evlenerek Almanya’ya gelen kadınların arkadaşları, dertten nasibini almış hikayelerini paylaşmalarında sakınca olduğunu düşünecekleri kişilerdir; başka bir deyişle eşinin arkadaşlarıdır. Eşinden bağımsız tanıdığı ve paylaştığı bilgiyi eşine götürmeyeceğine güvendiği insanlar bulmak ise sosyal hayata entegre olmaktan geçer. ${ }^{8}$ Sosyal hayata entegre olmak da belki yıllar alacaktır. Aile içinde huzuru sağlayabilme ve evliliği bir ömür sürdürebilme yetisi, Almanya'da zorlu yollardan geçmeyi işaret etmektedir. Kaya, bu bağlamda yaptığı görüşmelerden şöyle bir örnek paylaşıyor:

"Itthal gelin ve damatlar tam bir trajedi. Boşanmalar sayısız, dindar kesimde pek değil ama modern görünüşlü ailelerde çok.” (Kaya/Kentel, 2005, s.153)

"40 Metrekare Almanya" isimli filmde yönetmen Başer, evlenerek Almanya’ya gelen bir kadının hikâyesine dikkat çekiyor. Film koca rolündeki Dursun’un ataerkil davranışları ve bu davranışlarının Turna karakteri üzerindeki travmatik etkileri üzerinden ilerler. Dursun, genel geçer göçmen erkek profiline birebir uymaktadır. Almanya'da göçmen sineması, esas problem olarak yine ataerkil geleneklere gönderme yapar ve gurbette bu geleneklerin, asimilasyona direnmede bir savunma mekanizması olarak gelişen milliyetçilik ve muhafazakarlıkla harmanlanarak, kadınların üzerinde Türkiye'dekinden daha çok baskı oluşturduğunu görsel sanatlar aracılığıyla izleyenlere aktarır. Turna, kendi köyünde ona bırakılan mutfak gibi iç mekânların yanında, dış mekânda da görünür olmalarına olanak tanıyan tarla ve çeşme başı gibi sosyalleşme mekânlarından, Almanya'da bir köylüsü ile evlendirilerek alıkonulur. Köyünde babasının sahip olduğu baskıcı duruş, evlenerek el değiştirerek kocasına teslim edilir. Önceleri Almanya bilinmezlik içinde hoşgörünse de Turna'ya, kısa bir süre sonra esir bir hayata mekân tesis etmiş olmaktan başka birşeye hizmet etmeyecektir. Temizlik yaparken, kapının önünü silmek üzere dokunulan kapı kulpu, Turna’ya kafese kilitlenmiş hayvan hissi uyandırır. Dursun'a şöyle serzenişte bulunur:

8 Berlin'de kadınlarla yaptığım görüşmelerdeki çıkarımlarımdan. 


\section{- Kaplyı niye kitliyon? Ben hayvan miyım?}

Dursun'un cevabı, Almanya'daki göçmen erkeklerin karısını eve kilitleyerek ya da karısına bask1 uygulayarak, Almanya'da değişime engel olabileceği düşüncesine işaret etmektedir:

- $\quad$ Biz Almanya'daylz. Almanya bizim ülkeye benzemez. Sen bunların ne mal olduğunu bilmezsin. Hem sen kapının kilitli olduğunu nerden anladın? Dışarı mı çıkacaktın? Hadi, çık çık, $b * k$ var dışarda! (Başer, 1986)

Saybaş11’'nın belirttiği gibi, yönetmen Tevfik Başer, Turna ve Dursun karakterlerini izleyiciye göçmen kadınlar ve erkekler olarak anlayacağımız bir metafor olarak sunar. Turna'nın izleyiciye sunulan Almanya' daki esir hayatı, “tekil gerçekliğin çoğul öyküsüdür”(Saybaş11, 2011, s.185).

\section{İthal Çocuk Gelinler}

Avrupa kültürünün, evrensel olarak uygarlık yolunda model olarak kabul edilmesi, doğu kültürlerinin yok olması konusunda bir tehdit ortaya çıkardı. Avrupa, bu sebeple insan hakları alanında çalışanlar tarafından eleştirildi. Erken evlilik gibi bir zulmü, bir kültür olgusu haline getiren medeniyetlere bu tehdit sebebiyle hiç dokunulmaması da insan hakkı ihlali olarak görülmeliydi.

Göçmenler için, çocuk evlilikleri konusu birçok konuda olduğu gibi daha hassas olmaktadır. Göçmenler, kültürlerindeki köklü değişiklikleri ancak kendi kendilerine yaptıkları takdirde, kabul edebilmektedir fakat Almanya Hükümeti'nin bazı değişiklikleri entegrasyon için şart koşması, Türk topluluğu nezdinde asimilasyon örneği olabilmektedir ve bu kültüre sıkı sıkıya bağlanılması gibi tersi bir etki de yaratabilmektedir.

Almanya Hükümeti’nin göçmen topluluğunda karşılaştığı; “Aile Birleşimi Yasası” ile Türkiye'den gelen çocuk gelinlere yaşı dolayısıyla engel koymamış olması, evlenen kişilerin Almanya'da çalışan Türkiye vatandaşı olmalarındandı. (Türkiye vatandaşı göçmen işçilerin Türkiye yasalarındaki evlilik yaşını esas almaları kaçınılmazdı.)

Türkiye'nin yasaları önünde evli iki insanı, çocuk evliliği yapıldığı için Almanya'ya kabul etmemek evrensel yasalara aykırıydı. Fakat gelinler her şeyden önce çocuktu. Bu "kültürü" değiştirmeye çalışmak, Almanya'nın boynunda asılı duran 1rkçılığı başka bir boyutta da gösterebilirdi.

2007 y1lında yürürlüğe giren yasa ile "ithal gelin ve damat" olmak zorlaşmaya başladı. Bu evliliklere malvarlığı beyanı ve gelecek kişinin Almanca bilmesi gibi yasal zorunluluklar getirildi. Böyle bir zorunluluk göçmen kitlesi ve insan hakları savunucuları tarafından insan hakları ihlali olarak görülebilmektedir fakat çocuk gelinler açısından ele amak faydalı olacaktır.

Yasalarında evlilik yaşı 18 olan Almanya, yasalardaki bir nevi boşluk sebebiyle erken evlilik gibi bir insan hakkı ihlalini engelleyememiştir. Almanya belki de çocuk evliliğini engelleyerek, fizyolojik gelişimini ve eğitimini tamamlayamamış ve bu yüzden Almanya'da dört duvar arasında çocukluğunu ve emeğini heba edecek, cahil olmaya itilmiş çocuk gelinlerin hayatını kurtarmış olacaktır. Çünkü çocuk gelinlerin Almanya'da bundan sonraki hayatlarının neye tekabül ettiği bilinen bir gerçektir; şiddet gördüğünde sığınacağı baba ocağı yokluğu, şikayet edeceği kimsenin olmaması, hastanede darp izini görecek doktora mecburi dilsizliği, acil şiddet hattını bir ihtimal aradığında dile hakim olamadığından görevliler tarafından dikkate alınmama ve yine bir ihtimal gideceği mahkemede hakim önünde kendini savunma güçlüğü ve yine hayata karşı aciz kalma ve sadece çocuklarıyla anlam bulacak bir hayat. 


\section{Sonuç}

Ataerki, kadınların yüzyıllardır kurtulamadığı bir aidiyet ilişkisi oldu. Sistem maskelerini değiştiriyordu fakat arkasındaki yüz hep bâki oldu. Toplumsal cinsiyet konusu göç ile irdelendiğinde, göçmen kadınların iki kere öteki olduğu biliniyordu. Bunun yanında bulguları ters düz edecek birçok ek etken de olabilirdi; genç-yaşl1, zengin-fakir, dindar-ateist, eğitimli-eğitimsiz vb. Fakat aile birleşimi ile gelmiş, Türkiye doğumlu, Almanya'ya göç etmiş kadınların genellikle maruz kaldıkları problem; eğitimsizlik ve dil bilmemek üzerineydi. Araştırmalar sonucunda, göçün sebep olduğu problemleri erkekler ve kadınlar farklı gözlemliyor ve farklı yaşıyorlardı.

Türkiye'den Almanya'ya göç eden kadınların ait oldukları sosyal statüleri, sosyal ilişkileri ve tarihin bir yerinde köylerinde/kasabalarındaki Almanya'dakinden farklı hayatları, kadınların göç ettiklerinde bazı problemlerle karşılaşmalarına sebep oldu. Karşılaştıkları şiddet, Almanya'daki kadınların karşılaştığı şiddet ile temelinde aynıydı fakat Almanya ve Türkiye'deki kadınların deneyimledikleri şiddetin boyutları farklıydı. Böylesi bir durumda göçmen kadınlar, köksüz ağaçlar olarak tasvir edilebilir. Kadınlar Almanya'da kültürel olarak kök salamadıkları için, ardılları olan çocuklarının da Almanya'da karşılaştıkları sorunlar sebebiyle yaprak yaprak dökülmeleri olasıdır. Kadınların iki dominant kültür arasında sıkışıp kalmaları (Alman/Avrupa modernitesi-Türkiye/ Oryantal kültürel dokuları dahilindeki ataerki) kadınlar için hayatı güçleştirmektedir. Göçmen kadınlar bu iki kültürün baskıları altında ezilmektedir; anadil ve Alman diline hakim olamama sebebiyle kendini ifade edememe, kalifiye olmayan bir işgücü, kayıt dışı istihdam ve asosyal bir yaşam, kadınların Almanya'da karşılaştıkları bir hayatı tarif ediyor. Toplum tarafindan kabul edilmeyen ve marjinalize edilmiş bir topluma ait göçmen kadınlar, göçmen oldukları için öteki, kadın oldukları için de kendi diasporalarında öteki kılınmaktalar. Almanya'daki ötekiliklerini, "baskın kültüre benzemeye çalışarak(!)" (bu tanımlama Türkiyeli erkeklerin tanımlamasıdır; zira kadınların özgürlüğü Alman modernitesinin tasarrufunda değildir fakat Türkiyeli erkekler, kadınların özgürlüğü söz konusu olduğunda, kadınların Alman kültürüne doğru bir yol izlediklerine dair kanı oluştururlar) gidermeye çalıştıklarında, ait oldukları topluluktan şiddet ile karşılık gören kadınlar ne yapacaklarını bilemez halde savrulabiliyorlar. Bazen Almanya'nın entegrasyon politikalarını eleştirseler de söz konusu kadınlar olduğunda, kendi hayatlarının öznesi olabilmek adına Türkiyeli kadınlar, Almanya'nın eşitlikçi politikalarını anlamlı buluyorlar. ${ }^{9}$ Bu politikalar kendi pratiklerinde hayat bulduğunda ise karşılaştıkları tepkiler, kadınları hangi topluma ait olduklarına dair sordukları sorularla kimlik bunalımlarına itiyor. Bu da göçmen kadınları mücadele alanlarından alıkoyabiliyor. Kadınların eşit olabilmek uğruna adım attıkları her eylem, kendi kültürlerine bir ihanet olarak algılanabiliyor. Yaşadıkları tüm bu olumsuzluklar sebebiyle kadınlar, kendilerini ne Türkiyeli ne de Almanyalı hissederek, aidiyeti olmadan yaşadıkları bu dünyada ne kadar sahipsiz ve çaresiz olduklarını Almanya'da yaşanan kadın/namus cinayetleri ile tüm dünyaya bildiriyorlar. 2005 yılında Berlin'de kardeşleri tarafından öldürülen, namus cinayeti kurbanı Hatun Sürücü bu örneklerden yalnızca biridir ${ }^{10}$.

9 Almanya'da görüştüğüm kadınlardan edinilen genel kanı.

10 Bianet İnternet Gazetesi, Töre Cinayeti Almanya'nın da derdi (2005) http://bianet.org/kadin/kultur/57220-tore-cinayeti-avrupanin-da-derdi, 3 Kasım 2013 tarihinde ziyaret edildi. 


\section{Öneriler}

Almanya'daki namus cinayetleri, göçmen Türkiyeli halkların itibarının da her geçen gün zedelenmesine, Almanya'daki 1rkçı eylemlerin de buna bağlı olarak ayyuka çıkmasına zemin hazırlıyor. Bu cümlenin yazılmasındaki esas sebep; kadınlara acımayan bu zihniyetin, en azından kendilerinin Almanya'daki akıbetlerini düşünmeleri için, bir an önce kadına yönelik şiddete mahal verecek eylemlerini engellemeleri yönünde baskı unsuru olması istemiyle belirtilmiştir. Kız çocukların çocuk yaşta evlendirilip Almanya'ya gönderilerek eğitim hayatlarının yarıda kesildiği bir hayat, hem Türkiye'nin hem de Almanya'da bulunan Türkiyeli topluluğun kalkınmasının önünde büyük bir engeldir. Kalkınamayan bir Türkiye toplumu ise Avrupalıların gözünde hep ikincil vatandaş olmaya mahkumdur. Erkeklerin kendilerine sunulan özgürlüklere kendi kız kardeş, eş, anne ve kız çocuklarının da sahip olmaları gerektiğini savunmaları, yani eşitliğin önünü açmaları, erkeklerin de Almanya'daki hayatlarını güzelleştirecek, aile birleşimleri ile yerinden edilen kadınların hayatını güzelleştirmeye hizmet edecektir. Almanya hükümetinin politikalarını eleştirirken daha makul sebeplerle eleştirmiş olacaklardır. Kendisi mağdur olan bir topluluk, başka bir topluluk olan kadınları mağdur etmemelidir.

\section{Kaynakça}

Başer, T. (1986). 40 Metre Kare Almanya. Hamburg.

Bianet Internet Gazetesi (2005), Töre Cinayeti Almanya'nın da derdi, http://bianet.org/kadin/kultur/57220-tore-cinayeti-avrupanin-da-derdi (3 Kasim 2013 tarihinde ziyaret edildi).

Demirci, H. (1997). Almancıların Çocukları, Berlin: Halime Demirci Yayınları. İşveren Sendikaları Konfederasyonu (2006). Avrupa'daki Türk Kadını, http://tiskweb.com/yayinlar.asp?sbj=ana\&a-

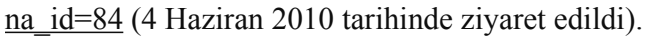

Kaya, A. / Kentel, Ferhat (2005), Euro-Türkler: Türkiye ile Avrupa Birliği arasında köprü mü, engel mi? : Almanya-Türkleri ve Fransa-Türkleri üzerine karşılaştırmalı bir çalışma. İstanbul: İstanbul Bilgi Üniversitesi Yayınları.

Özyurt, E. (2010) Impact of Migration on Women from Turkey: Case of Germany, Berlin.

Peköz, M. (2002). Avrupa Birliği’nde Göçmenler; Almanya'da Türkler/Kürtler, İstanbul: Gün Yayıncılık.

Saybaşıl1, N. (2011). Sinırlar ve Hayaletler: Görsel Kültürde Göç Hareketleri (B. Doğan, Çev.). İstanbul: Metis Yayınları. 